\title{
DID JESUS EVER TEACH IN GREEK?
}

\author{
Stanley E. Porter
}

\section{Summary}

This paper argues-against the general scholarly consensus-that Jesus not only had sufficient linguistic competence to converse with others in Greek but also even to teach in Greek during his ministry. After an introduction to the possible languages of Jesus (Aramaic, Hebrew and Greek), the evidence for the widespread use of Greek, especially in Galilee, is examined: the role of Greek as the lingua franca of the Graeco-Roman world; the geographic and epigraphic-literary evidence for Greek in Lower Galilee and Palestine; and Jesus' use of Greek according to the New Testament. Several significant New Testament passages are examined, including Jesus' trial before Pilate and Jesus' discussion with his disciples at Caesarea Philippi, along with several others.

\section{Introduction}

Regarding the question of the languages Jesus may have known and used in his itinerant ministry, current scholarly opinion follows the conclusion of Dalman, who stated that, though Jesus may have known Hebrew, and probably spoke Greek (N.B.), he certainly taught in Aramaic. ${ }^{1}$ With this

${ }^{1}$ G. Dalman, Jesus-Jeshua: Studies in the Gospels (trans. P.P. Levertoff; London, SPCK 1929) 1-37; see also P. Lapide, 'Insights from Qumran into the Languages of Jesus', RevQ 8 (1975) 483-86; M. Black, An Aramaic Approach to the Gospels and Acts (3rd ed.; Oxford, Clarendon Press 1967) 16 n. 1, cf. 47-49; J. Fitzmyer, 'The Languages of Palestine in the First Century A.D.', in S.E. Porter (ed.), The Language of the New Testament: Classic Essays (Sheffield, JSOT Press 1991) 126-62 (the latest corrected version of an article that originally appeared in $C B Q 32$ [1970] 501-531); idem, 'Did Jesus Speak Greek?' BAR 18 (1992) 58-77 (a popular form of the above); M. Wise, 'Languages of Palestine', Dictionary of Jesus and the Gospels (ed. J.B. Green and S. McKnight; Downers Grove, InterVarsity Press 1992) 434-44; G. Mussies, 'Languages (Greek)', ABD 4.195-203; and L.L. Grabbe, Judaism from Cyrus to Hadrian (2 vols.; Minneapolis, Fortress 1992) esp. 1.156-58 on language. The following summary and assessment of the evidence for the use of Aramaic, Hebrew and Greek is directly dependent upon S.E. Porter, Verbal Aspect in the Greek of the New Testament, with Reference to Tense and Mood (New York, Lang 1989) 111-17 esp. 112-13; and idem, 'Introduction: The Greek of the New Testament as a Disputed Area of Research', in Porter (ed.), Language of the New Testament, 11-38 esp. 22-25. See also G.H.R. Horsley, New Documents Illustrating Early Christianity, vol. 5: 
conclusion long maintained, it might seem unnecessary to undertake again an investigation of this topic, except for the fact that it is still not commonly recognized just how strong the probability-even likelihood-is that Jesus not only had sufficient linguistic competence to converse with others in Greek but also even to teach in Greek during his ministry. ${ }^{2}$ Once the barrier to Jesus' speaking Greek is crossed and the category of Jesus' teaching in Greek is entertained, this has direct implications for exegesis that I will attempt to exploit in this paper.

\section{The Possible Languages of Jesus: Aramaic, Hebrew and Greek}

Although the evidence is not as strong as some would contend, it has long been agreed by many scholars that Aramaic was the predominant language of the indigenous Jewish population of Palestine and the primary language of Jesus. ${ }^{3}$ This Aramaic hypothesis rests securely upon the fact that, though Greek was the lingua franca of the Graeco-Roman world, in Palestine it never fully replaced Aramaic, an important Semitic language used by the Jewish population in Palestine after the Exile. The widespread use of Aramaic is substantiated, according to this hypothesis, not only by the Aramaic portions of the biblical writings of Daniel and Ezra and by noncanonical 1 Enoch, but by a large amount of inscriptional, ossuary, epistolary, papyrological and literary evidence, especially now from Qumran but also from the other Judaean Desert sites (e.g. Murabba'at, Masada and Nahal Hever). Although it was once

Linguistic Essays (New South Wales, Australia, Macquarie University 1989) 19-26. Latin is not dealt with here, since it is not seriously considered as a language of Jesus by recent scholars, although it was used by some Romans resident in Palestine, especially government officials. See Jn. 19:20, where the titlulus is reported as being written in Latin, Greek and Hebrew or Aramaic.

${ }^{2} \mathrm{~A}$ related topic of comparable significance is the nature of the Greek of the New Testament. Many scholars are apparently even less aware of this discussion than they are of the one with which this paper is concerned. For a summary of the history of discussion, as well as classic statements of the major positions in this century, see Porter (ed.), Language of the New Testament.

${ }^{3}$ See F. Büchsel, 'Die griechische Sprache der Juden in der Zeit der Septuaginta und des NT', ZAW 60 (1944) 133-42. 
thought by some scholars that Aramaic had entered a period of decline in the two centuries on either side of Christ's birth, ${ }^{4}$ in the last fifty years many important discoveries have confirmed the significant place of the Aramaic language,, 5 although there is still some debate regarding the dialect of Aramaic that was spoken. ${ }^{6}$ While it is likely that Jesus' primary language was Aramaic, this position is argued primarily by logical and historical inference, ${ }^{7}$ since Jesus is not recorded as using Aramaic apart from several odd quotations (e.g. Mk. 5:41, 7 7:34, 15:34 par. Mt. 27:46; where he is quoted as uttering complete clauses). ${ }^{9}$ Also, the majority of documentary evidence is of a literary quality, some quite late, while the inscriptional evidence, some of which could be Hebrew, is limited mostly to

${ }^{4}$ E.g. W.F. Albright, The Archaeology of Palestine (rev. ed.; Baltimore, Penguin 1960) 201-202.

${ }^{5}$ For surveys of the evidence, see esp. J.A. Fitzmyer and D.J. Harrington, $A$ Manual of Palestinian Aramaic Texts (Rome, Biblical Institute Press 1978); Fitzmyer, 'Languages of Palestine', 147-58; idem, 'The Contribution of Qumran Aramaic to the Study of the New Testament', NTS 20 (1973-74) 383-407; K. Beyer, Die Aramäische Texte vom Toten Meer (Göttingen, Vandenhoeck \& Ruprecht 1984); E. Schürer, The History of the Jewish People in the Age of Jesus Christ (3 vols.; rev. G. Vermes, F. Millar and M. Black; Edinburgh, Clark 1973-86) 2.23-26; and E.M. Meyers and J.F. Strange, Archaeology, the Rabbis and Early Christianity (London, SCM 1981) 73-78.

${ }^{6}$ For the two sides of this debate, see E.Y. Kutscher, 'The Language of the Genesis Apocryphon-A Preliminary Study', Hebrew and Aramaic Studies (ed. Z. Ben-Hayyin et al.; Jerusalem, Magnes 1977) esp. 9, 12-16; P. Kahle, 'Das palästinische Pentateuchtargum und das zur Zeit Jesu gesprochene Aramäisch', ZNW 49 (1958) 100-115; idem, The Cairo Geniza (2nd ed.; Oxford, Blackwell 1959) esp. 191-208.

7Some may be surprised that I refer to the 'inference' that Jesus spoke and taught in Aramaic. The confirmatory 'proof' often marshalled that Jesus taught in Aramaic is the several quotations from Aramaic cited in the Gospels. By this reasoning it is more plausible to argue that Jesus did most of his teaching in Greek, since the Gospels are all Greek documents. In fact, on one occasion when Jesus spoke Aramaic (Mk. 15:34), he was apparently misunderstood by those standing by, possibly implying that they did not understand Aramaic or may not have been used to hearing it. And this occurred in Jerusalem, the supposed center of Semitic language Judaism.

${ }^{8}$ This Aramaic phrase may be attested in a Jewish epitaph in Greek from Tiberias, unfortunately undated. See NewDocs 1 (1976) 72.

9J. Jeremias (New Testament Theology [London, SCM 1971] 4-6) counts 26 Aramaic words in all in the Gospels. 
proper names. 10 Nevertheless, this theory has many important supporters and almost assuredly will continue to dominate scholarly discussion. ${ }^{11}$

${ }^{10}$ As Fitzmyer recognizes ('Languages of Palestine', 149).

${ }^{11 B e s i d e s}$ those noted above, see W. Sanday, 'The Language Spoken in Palestine at the Time of our Lord', Expositor Series 1, 7 (1878) 81-99; idem, 'Did Christ Speak Greek?-A Rejoinder', Expositor Series 1, 7 (1878) 368-88 (to A. Roberts); A. Meyer, Jesu Muttersprache: Das galiläische Aramäisch in seiner Bedeutung für die Erklärung der Reden Jesu und der Evangelien überhaupt (Freiburg, Mohr [Siebeck] 1896); J. Wellhausen, Einleitung in die drei ersten Evangelien (Berlin, Reimer 1905), although compare the second edition of 1911; E. Nestle, Philologica Sacra: Bemerkungen über die Urgestalt der Evangelien und Apostelgeschichte (Berlin, Reuther und Reichard 1896); G. Dalman, The Words of Jesus: Considered in the Light of Post-Biblical Jewish Writings and the Aramaic Language (trans. D.M. Kay; Edinburgh, Clark 1902); C.C. Torrey, 'The Translations Made from the Original Aramaic Gospels', Studies in the History of Religions (FS C.H. Toy; ed. D.G. Lyon and G.F. Moore; New York, Macmillan 1912) 269-317; idem, Our Translated Gospels: Some of the Evidence (Cambridge, MA, Harvard University Press 1916); idem, 'The Aramaic of the Gospels', in Porter (ed.), Language of the New Testament, 98-111 (originally published in JBL 61 [1942] 71-85); idem, 'Studies in the Aramaic of the First Century A.D.', ZAW 65 (1953) 228-47; C.F. Burney, The Poetry of our Lord (Oxford, Clarendon Press 1925); P. Joüon, 'Quelques aramaïsmes: Sous-jacent au grec des Évangiles', RSR 17 (1927) 210-29; R.O.P. Taylor, 'Did Jesus Speak Aramaic?' ExpT 56 (1944-45) 95-97; idem, The Groundwork of the Gospels with Some Collected Papers (Oxford, Blackwell 1946); G. Bardy, La question des langues dans l'église ancienne (vol. 1; Paris, Beauchesne 1948); H.M. Draper, 'Did Jesus Speak Greek?' ExpT 67 (1955-56) 317; R. McL. Wilson, 'Did Jesus Speak Greek?' ExpT 68 (1956-57) 121-22; M. Black, 'The Recovery of the Language of Jesus', NTS 3 (1956-57) 305-313; idem, 'Second Thoughts-IX. The Semitic Element in the New Testament', ExpT 77 (1965-66) 20-23; idem, 'Aramaic Studies and the Language of Jesus', in Porter (ed.), Language of the New Testament, 112-25 (originally published in In Memoriam Paul Kahle [ed. M. Black and G. Fohrer; Berlin, Töpelmann 1968] 17-28); J.A. Emerton, 'Did Jesus Speak Hebrew?' JTS NS 12 (1961) 189-202; J. Barr, 'Which Language did Jesus Speak?-Some Remarks of a Semitist', BJRL 53 (1970) 9-29; F. Zimmermann, The Aramaic Origin of the Four Gospels (New York, Ktav 1979) esp. 3-23; M. Wilcox, 'Semitisms in the New Testament', ANRW II.25.2 (ed. W. Haase; Berlin, de Gruyter 1984) 979-86; L.H. Feldman, 'How Much Hellenism in Jewish Palestine?' HUCA 57 (1986) 83-111; G. Schwarz, 'Und Jesu Sprach': Untersuchungen zur aramäischen Urgestalt der Worte Jesu (2nd ed.; Stuttgart, Kohlhammer 1987); J.P. Meier, A Marginal Jew: Rethinking the Historical Jesus, vol. 1: The Roots of the Problem and the Person (New York, Doubleday 1991) esp. 255-68. See also H. Ott, 'Um die Muttersprache Jesu: Forschungen seit G. Dalman', NovT 9 (1967) 1-25. 
A small group of scholars has maintained, however, that some form of Hebrew, whether biblical or Mishnaic, had a far greater importance in first-century Palestine than has been fully appreciated. Segal proposed that Mishnaic Hebrew, rightly considered by him to be the linguistic evolutionary offspring of biblical Hebrew, and much in evidence in the rabbinic writings as independent of Aramaic (which was thought by Birkeland to be reserved for the upper classes), was a prominent Jewish vernacular at all social levels from approximately 400 B.C. to A.D. 150.12 The Hebrew Judaean Desert documents, including those from Qumran (which apparently outnumber those in Aramaic), but especially the Hebrew Bar Kokhba letters, ${ }^{13}$ have given further credence to the theory of vernacular Hebrew. ${ }^{14}$ There is some ossuary, numismatic and literary (e.g. Ben Sira) evidence for Hebrew as well. Although there is still disagreement over the exact nature of this Hebrew and its extent of use, a number of scholars still consider Mishnaic Hebrew to be a probable language of the first century and a possible if not a probable language of Jesus. ${ }^{15}$ Although Jesus may have known sufficient Hebrew to read from Isaiah as recorded in Luke 4:16-30, and Hebrew was probably used in Palestine in some capacity, perhaps by the Jewish leaders or in certain religious rituals, 'evidence for colloquial Hebrew is not abundant', 16 with a surprisingly small number of Hebrew inscriptions in Palestine.

${ }^{12}$ M.H. Segal, 'Mishnaic Hebrew and its Relation to Biblical Hebrew and to Aramaic', JQR 20 (1908) 670-700, 734-37; idem, A Grammar of Mishnaic Hebrew (Oxford, Clarendon Press 1927) 5-19. He is followed in his major theories by H. Birkeland, The Language of Jesus (Oslo, Dybwad 1954).

${ }^{13}$ For the evidence, see Meyers and Strange, Archaeology, 66-73; Fitzmyer, 'Languages of Palestine', 158-62.

${ }^{14}$ See Barr, 'Which Language', 20; cf. R.H. Gundry, 'The Language Milieu of First-Century Palestine: Its Bearing on the Authenticity of the Gospel Tradition', JBL 83 (1964) 405-407.

${ }^{15}$ T.W. Manson, The Teaching of Jesus: Studies of its Form and Content (2nd ed.; Cambridge, Cambridge University Press 1935); J.M. Grintz, 'Hebrew as the Spoken and Written Language in the Last Days of the Second Temple', JBL 79 (1960) 32-47; Emerton, 'Did Jesus Speak Hebrew?'; idem, 'The Problem of Vernacular Hebrew in the First Century A.D. and the Language of Jesus', JTS NS 24 (1973) 1-23; C. Rabin, 'Hebrew and Aramaic in the First Century', CRINT (section 1; vol. 2; ed. S. Safrai and M. Stern; Assen, Van Gorcum 1976) 1007-1039.

16Fitzmyer, 'Languages of Palestine', 161. 
Finally, a third group of scholars has argued for the predominant role of Greek in first-century A.D. Palestine and, consequently, for the strong possibility of its use by Jesus. The arguments for this position rest firmly on the role of Greek as the lingua franca of the Roman Empire, the linguistic and cultural character of lower Galilee during the first century, the linguistic fact that the New Testament has been transmitted in Greek from its earliest documents, a diversity of epigraphic evidence, significant literary evidence, and several significant contexts in the Gospels that give plausibility to this hypothesis. Whereas no contemporary scholar would probably argue that Jesus spoke only Greek, a number of scholars have argued in various ways that Greek was in widespread use by upwards of a majority of Jews in the multilingual society of first-century Palestine ${ }^{17}$ and, therefore, may well have been a language of Jesus at least on occasion.

17Besides those cited above, such as Dalman, Black, Rabin, Barr, Bardy, Birkeland, Emerton, Lapide, Gundry, Meyers and Strange, Fitzmyer, and Meier who mention the possibility of at least a trilingual community, see A. Roberts, Greek: The Language of Christ and his Apostles (London, Longmans, Green 1888) (cf. idem, 'That Christ Spoke Greek', Expositor Series 1, 6 [1877] 81-96, 161-76, 285-99, 307-383; 'That Christ Spoke Greek-A Reply', Expositor Series 1, 7 [1878] 278-95 [to W. Sanday]); T.K. Abbott, Essays, Chiefly on the Original Texts of the Old and New Testaments (London, Longmans, Green 1891) esp. 129-82; E.A. Abbott, Johannine Grammar (London, A. \& C. Black 1906); S.W. Patterson, 'What Language did Jesus Speak?' The Classical Outlook 23 (1946) 65-67 (who gives serious consideration to Latin as a language of Jesus); A.W. Argyle, 'Did Jesus Speak Greek?' ExpT 67 (1955-56) 92-93, 383; idem, 'Greek among the Jews of Palestine in New Testament Times', NTS 20 (1973-74) 87-89; M. Smith, 'Aramaic Studies and the Study of the New Testament', JBR 26 (1958) 304313; N. Turner, 'The Language of Jesus and his Disciples', in Porter (ed.), Language of the New Testament, 174-90 (originally published in N. Turner, Grammatical Insights into the New Testament [Edinburgh, Clark 1965] 17488); idem, 'Were the Gospels Written in Greek or Aramaic?' EvQ 21 (1949) 42-48; idem, 'The Unique Character of Biblical Greek', VT 5 (1955) 208-213; idem, 'The Language of the New Testament', Peake's Commentary on the Bible (ed. M. Black and H.H. Rowley; London, Nelson 1962) 659-62; idem, 'The Literary Character of New Testament Greek', NTS 20 (1973-74) 107114; idem, 'The Quality of the Greek of Luke-Acts', Studies in New Testament Language and Text (ed. J.K. Elliott; Leiden, Brill 1976) 387-400; idem, 'Biblical Greek: The Peculiar Language of a Peculiar People', SE 7, 505-512; idem, Syntax, vol. 3 of A Grammar of New Testament Greek, by J.H. Moulton (Edinburgh, Clark 1976) esp. 1-10; S. Lieberman, Greek in Jewish 
In considering the strength of this position in more detail, its several lines of support will be considered in turn, illustrating the strength and integrity of the position on the basis of accumulated evidence. This evidence clearly points to the presumption that Jesus' productive bilingual capacity included the ability to speak and possibly to teach in Greek and, furthermore, that we may have several important contexts in which Jesus spoke Greek.

\section{Greek as the Lingua Franca of the Graeco-Roman World}

That Greek was the lingua franca of the Graeco-Roman world and the predominant language of the Roman Empire is acknowledged by virtually everyone who has considered this issue, although the full significance of this factor has not been fully appreciated by all New Testament scholars. ${ }^{18}$ The so-

Palestine: Studies in the Life and Manners of Jewish Palestine in the II-IV Centuries C.E. (2nd ed.; New York, Feldheim 1965); idem, 'How Much Greek in Jewish Palestine?' Biblical and Other Studies (ed. A. Altmann; Cambridge, MA, Harvard University Press 1963) 123-41; K. Treu, 'Die Bedeutung des Griechischen für die Juden im römischen Reich', Kairos 15 (1973) 123-44; H. Leclercq, 'Note sur le grec néo-testamentaire et la position du grec en Palestine au premier siecle', Les études classiques 42 (1974) 243-55; P. Hughes, 'The Language Spoken by Jesus', New Dimensions in New Testament Study (ed. R.N. Longenecker and M.C. Tenney; Grand Rapids, Zondervan 1974) 127-43; M. Hengel, Judaism and Hellenism: Studies in their Encounter in Palestine during the Early Hellenistic Period (London, SCM 1974); idem, Between Jesus and Paul: Studies in the Earliest History of Christianity (Philadelphia, Fortress 1983) esp. 1-29; idem, The 'Hellenization' of Judaea in the First Century after Christ (London, SCM 1989) esp. 7-18; G. Mussies, 'Greek in Palestine and the Diaspora', CRINT, 1040-1064; idem, 'Greek as the Vehicle of Early Christianity', NTS 29 (1983) 356-69; J.M. Ross, 'Jesus's Knowledge of Greek', IBS 12 (1990) 41-47; J.W. Voelz, 'The Linguistic Milieu of the Early Church', CTQ 56.2-3 (1992) 8197.

${ }^{18}$ Hengel (Judaism and Hellenism, 58-64 esp. 61), followed by Meyers and Strange (Archaeology, 78), Fitzmyer ('Languages of Palestine', 134) and others, has shown that there were Greek elements in Palestine even before Alexander the Great, such as evidence of Greek pottery, instances of Greek architecture and the use of Greek names. For a list of Greek names used in Palestine around the New Testament period, see Schürer, History, 2.73-74. B. Sass ('Arabs and Greeks in Late First Temple Jerusalem', PEQ [January-June 1990] 59-61) claims that he may have identified the earliest Palestinian shards with Greek inscriptions, dating to the sixth century B.C. Besides Hengel, for discussion of hellenistic influence on the Jews, see J.D. 
called classical period of Greek developed away from the use of a number of independent regional languages or dialects, 19 which were distinguished by broad phonological, morphological and lexical differences, toward the ascendance of a single dialect, Attic Greek, which formed the basis (along with the regularizing influence of literary or official Ionic) of hellenistic Greek.20 During the period of Alexander (educated by Aristotle, who used a pre-hellenistic form of Greek himself) and the Diadochi, the already ascendant regional variety, Attic, due especially to its cultural and economic superiority initiated under Philip II of Macedon, began a process of regularization and systematization on the basis of the interplay of linguistic innovation and tradition. ${ }^{21}$ As the various propagators (soldiers, merchants, etc.) of Greek moved further from their language bases and mingled with those still using other regional dialects, the result was a standardization of Greek varieties into a 'common dialect'. As this prestige language spread, startling consequences of foreigners speaking Greek could have been expected, but these appear to have been

Newsome, Greeks, Romans, Jews: Currents of Culture and Belief in the New Testament World (Philadelphia, Trinity Press International 1992), although he fails to make some of the important linguistic distinctions Hengel does. ${ }^{19}$ See J. Lyons, Introduction to Theoretical Linguistics (Cambridge, Cambridge University Press 1968) 33-36; cf. A. Thumb, Die griechischen Sprache im Zeitalter des Hellenismus: Beiträge zur Geschichte und Beurteilung der KOINH (Strassburg, Trübner 1901) 162-63. On the changing fortunes of the dialects, see C.D. Buck, The Greek Dialects: Grammar, Selected Inscriptions, Glossary (Chicago, University of Chicago Press 1955) 141-72; P.W. Costas, An Outline of the History of the Greek Language, with Particular Emphasis on the Koine and the Subsequent Periods (Chicago 1936; repr. Chicago, Ares 1979) 32-40.

$20 \mathrm{On}$ the history of hellenistic Greek, see E. Schwyzer, Griechische Grammatik (2 vols.; Munich, Beck 1939, 1950) 1.116-31; A. Meillet, Aperçu d'une histoire de la langue grecque (3rd ed.; Paris, Hachette 1930) 245-54; Costas, Outline, 27-71 esp. 41-57; R. Browning, Medieval and Modern Greek (2nd ed.; Cambridge, Cambridge University Press 1983) 19-52; J. Humbert, Histoire de la langue grecque (Paris, Universitaires 1972) 115-26; A. López Eire, 'Del ático a la koiné', Emerita 49 (1981) 377-92; L.R. Palmer, The Greek Language (London, Faber and Faber 1980) 189-90, refuting P. Kretschmer, Einleitung in die Geschichte der griechischen Sprache (Göttingen, Vandenhoeck \& Ruprecht 1896) 410-17.

21Meillet, Histoire, 24-44, 247-51; Browning, Greek, 30-36; Costas, Outline, 58-70. 
'reasonably slight',22 virtually confined to enrichment of the lexicon and local variances in pronunciation. ${ }^{23}$ Hellenistic Greek then held sway as a single essentially sub-dialectless variety until the Byzantine and modern periods, when modern Greek again developed dialectical distinctives.

Despite a reasonable consensus on the development of hellenistic Greek (in conjunction with the widespread hellenistic cultural dissemination that took place under the Diadochi and the Herods, as well as the Hasmonaeans), ${ }^{24}$ there are still a number of linguistic issues that warrant further clarification. For example, frequent disparaging comments about hellenistic Greek being bad or sloppy in comparison to classical Greek must be ignored. These kinds of comments seem to derive from those who fail to understand the highly literary nature of the classical Greek texts used for comparison, even in such a popular author as Aristophanes; 25 the lack of direct access to the language used in everyday speech by the Attic population; 26 and the relatively value-free natural

22Palmer, Greek Language, 175.

${ }^{23}$ Although Thumb (Sprache, 167-69) identifies five different pronunciation areas, he also notes the inflexibility of hellenistic Greek in relation to other languages. It has been argued that the Greek of the Egyptian papyri was influenced by various Semitic languages and therefore does not constitute an accurate representation of hellenistic Greek. See e.g. L.-Th. Lefort, 'Pour une grammaire des LXX', Muséon 41 (1928) 152-60; J. Vergote, 'Grec Biblique', DBSup3 (ed. L. Pirot; Paris, Librairie Letouzey et Ane 1938) cols. 1353-60; F. Gignac, A Grammar of the Greek Papyri of the Roman and Byzantine Periods (Milan, Istituto Editoriale Cisalpino 1976, 1981) 1.46-48; idem, 'The Language of the Non-Literary Greek Papyri', Proceedings of the Twelfth International Congress of Papyrology (ed. D.H. Samuel; Toronto, Hakkert 1970) 137-52; idem, 'The Papyri and the Greek Language', Yale Classical Studies 28 (1985) 157-58. S.-T. Teodorsson argues against this, claiming that no other kind of Greek has ever been found in Egypt, thus there is no evidence of a previous 'pure' Greek, no evidence of the creolization process being argued for, and no evidence of this Greek being considered as in any way departing from the acceptable norms of hellenistic Greek (The Phonology of Ptolemaic Koine [Gothenburg, Acta Universitatis Gothoburgensis 1977] 25-35).

${ }^{24}$ Hengel, 'Hellenization', 8 and passim.

25K.J. Dover, 'The Colloquial Stratum in Classical Attic Prose', Classical Contributions (FS M.F. McGregor; ed. G.S. Shrimpton and D.J. McCargar; Locust Valley, NY, Augustin 1981) esp. 16.

265.-T. Teodorsson, 'Phonological Variation in Classical Attic and the Development of Koine', Glotta 57 (1979) esp. 68-71. 
development of languages, in which they must be evaluated according to their own linguistic systems. ${ }^{27}$ A second issue requiring further exploration is the issue of what is called linguistic register, in which a given linguistic code or system may be utilized by speakers or writers in various contexts to accomplish a variety of purposes. ${ }^{28}$ Hellenistic Greek had its own register system, in which the often vulgar language of papyri texts must be distinguished from literary texts such as those of Josephus and the Atticistic texts of Plutarch.29 A final factor to consider is the role of prestige languages within a multilingual environment. 30 Prestige languages are those languages that dominate the political, educational and economic forces at play in a language milieu. In Palestine, the

${ }^{27}$ See A. Thumb, 'On the Value of Modern Greek for the Study of Ancient Greek', Classical Quarterly 8 (1914) 182. As F. Blass says, 'the Hellenistic language as a whole is in its own way not less subject to rules nor less systematic than Attic' (Grammar of New Testament Greek [trans. H.St.J. Thackeray; 2nd ed.; London, Macmillan 1911] 3; see H.St.J. Thackeray, $A$ Grammar of the Old Testament in Greek according to the Septuagint [Cambridge, Cambridge University Press 1909] 21). Cf. R. Hudson, Sociolinguistics (Cambridge, Cambridge University Press 1980) 30ff.

${ }^{28} \mathrm{M}$. Gregory and S. Carroll, Language and Situation: Language Varieties and their Social Contexts (London, Routledge and Kegan Paul 1978) 75-85; M.A.K. Halliday, 'Register Variation', in Halliday and R. Hasan, 'Text and Context: Aspects of Language in a Social-Semiotic Perspective', Sophia Linguistica 6 (1980) 60-75; cf. Hudson, Sociolinguistics, 48-53.

${ }^{29}$ See Porter, Verbal Aspect, esp. 152-54; B.G. Mandilaras, The Verb in the Greek Non-Literary Papyri (Athens, Hellenic Ministry of Culture and Sciences 1973) 45-46; L. Rydbeck, 'On the Question of Linguistic Levels and the Place of the New Testament in the Contemporary Language Milieu', in Porter (ed.), Language of the New Testament, 191-204 (originally published in L. Rydbeck, Fachprosa, vermeintliche Volkssprache und Neues Testament: Zur Beurteiling der sprachlichen Niveauunterschiede im nachklassischen Griechisch [Uppsala, 1967] 186-99).

${ }^{30} \mathrm{M}$. Silva, 'Bilingualism and the Character of Palestinian Greek', in Porter (ed.), Language of the New Testament, 206-210 (originally published in Bib 61 [1980] 198-219); J.H. Moulton, Prolegomena, vol. 1 of $A$ Grammar of New Testament Greek (3rd ed.; Edinburgh, Clark 1908) 6-8; Vergote, 'Grec', cols. 1360-1367 esp. 1366-67; Horsley, New Documents Illustrating Early Christianity, 23-25.; cf. E. Haugen, 'Problems of Bilingualism', Lingua 2 (1950) 278; E. Oksaar, 'Bilingualism', Current Trends in Linguistics 9 (1972) 476-511; H. Baetens Beardsmore, Bilingualism: Basic Principles (2nd ed.; Clevedon, England, Multilingual Matters 1987) esp. 152-78. This point is not considered by many who discuss the question, and its importance is misunderstood by Meier (Marginal Jew, 291 n. 21, 294 n. 39). 
prestige language was Greek, even if Greek was not the first language for a significant number of its speakers. This means that there would have been cultural, social and especially linguistic pressure to learn Greek in order to communicate broadly within the social structure.

It is in the Greek language that the Gospels are written, although it has frequently been debated whether the Gospels were originally written in Greek and how Semitic the Greek is in which they are written. ${ }^{31}$ It is well beyond the scope of this paper to raise the question of whether the Gospels were originally written in a language other than Greek, although it is fair to say that the clear scholarly consensus is that whether or not Jesus originally spoke in Aramaic (as most scholars believe that he did), the Gospels themselves are not literalistic translations, even where they purport to record Jesus' words. As Black admits regarding the Greek of the Gospels, the "translation" is not literal but literary; in other words, it is doubtful if it can be justly described as translation at all in some cases. . The Evangelists, that is to say, are for the most part writing Greek Gospels, even where they are dependent upon sources.' 32 The history of this debate over the nature of the Greek of the Gospels is not necessary to pursue here, except to note that it is in this language, Greek, that the New Testament has been preserved and transmitted.

\section{The Influence of Greek in Lower Galilee and Palestine}

\section{Geography}

Regarding the influence of Greek in lower Galilee, ${ }^{33}$ evidence is increasing that it was the Palestinian area most heavily

${ }^{31}$ Against the idea that there existed a Jewish-Greek dialect, see Porter, Verbal Aspect, 113-17, 141-56; Horsley, New Documents Illustrating Early Christianity, 5-40.

32Black, Aramaic Approach, 274. He cites two exceptions: the parable of the sower (Mk. 4:2-9) and the parable of the well-behaved guest (Mt. 20:28), although here he depends on $D$.

33On defining the boundaries of Galilee, see Josephus, J.W. 3.35-40; cf. also Ant. 5.63, 86, 91; 8.142; E.M. Meyers, 'Galilean Regionalism as a Factor in Historical Reconstruction', BASOR 221 (1976) 93-101; and Meyers and Strange, Archaeology, 35-47. A shift may be occurring in opinion regarding how isolated upper Galilee was from hellenistic influence. See D. Edwards, 'First Century Urban/Rural Relations in Lower Galilee: Exploring the Archaeological and Literary Evidence', SBLSP 1988, 179-80 
influenced by Greek language and culture. ${ }^{34}$ Referred to as the 'Galilee of the Gentiles' in Matthew 4:15, lower Galilee was a center for trade among the Mediterranean, Sea of Galilee and Decapolis regions. Galilee was completely surrounded by hellenistic culture, with Acco-Ptolemais, Tyre and Sidon in the west and north-west, Panias-Caesarea Philippi, Hippos and Gadara in the north-east, east and south-east, and Scythopolis

and n. 64 with bibliography; idem, 'The Socio-Economic and Cultural Ethos of the Lower Galilee in the First Century: Implications for the Nascent Jesus Movement', in L.I. Levine (ed.), The Galilee in Late Antiquity (New York, Jewish Theological Seminary of America 1992) esp. 70-71. For a less optimistic perspective on the hellenistic influences on Galilee, see $S$. Freyne, Galilee from Alexander the Great to Hadrian 323 B.C.E. to 135 C.E.: A Study of Second Temple Judaism (Notre Dame, University of Notre Dame 1980) passim (but cf. p. 139 n. 90), who emphasizes the cultural and economic but not the linguistic factors.

${ }^{34}$ The degree of Greek penetration of rural Palestine is discussed in A.H.M. Jones, The Greek City: From Alexander to Justinian (Oxford, Clarendon Press 1940) 289-95; T. Rajak, Josephus: The Historian and his Society (London, Duckworth 1983) 46-64; T. Tcherikover, Hellenistic Civilization and the Jews (Philadelphia, Jewish Publication Society of America 1959) 114-16; and Hengel, Judaism and Hellenism, 58-106, who corrects Tcherikover. As one indication of the pervasive influence of Greek, in Acts 6:1 (cf. 9:29) a distinction is made between 'E $\lambda \lambda \eta \nu \imath \sigma \tau \alpha i$ and Eßpoiol, probably a linguistic distinction made between Jews who spoke mainly Greek and those who spoke mainly Aramaic or who also spoke Aramaic. Before the third century A.D. these terms were virtually exclusively linguistic terms referring to language competence. To distinguish those outside Palestine as Greek speakers would not have been necessary (it would have been assumed), but apparently there was a significant part of the population that spoke mostly Greek even of those resident in Jerusalem. For the evidence of this, see Hengel, Judaism and Hellenism, 2 with notes, 58; idem, Between Jesus and Paul, 8-9 with notes; idem, 'Hellenization', 7-8 with notes; and idem, The Pre-Christian Paul, with R. Deines (London, SCM 1991) 54-55, who estimates that $10-15 \%$ of the inhabitants of Jerusalem spoke Greek as their native language. He follows C.F.D. Moule, 'Once More, Who were the Hellenists?' ExpT 70 (1958-59) 100-102; Fitzmyer, 'Languages of Palestine', 144. This is further confirmed by C.C. Hill, Hellenists and Hebrews: Reappraising Division within the Earliest Church (Minneapolis, Fortress 1992) 22-24; and now A. Brehm, 'The Meaning of 'E $\mathrm{\lambda} \lambda \eta v i \sigma \tau$ ' in Acts in Light of a Diachronic Analysis of 'E$\lambda \lambda \eta v i \zeta \varepsilon v^{\prime}$ ', a paper delivered to the Section on Biblical Greek Language and Linguistics, at the Annual Meeting of the Society of Biblical Literature, 21-23 November 1993. The seven men appointed in Acts 6:5 to serve the Greek-speaking constituency all have Greek names. 
and Gaba in the south. ${ }^{35}$ Besides being connected by a number of waterways, there was a road system that utilized a series of valleys to interconnect the Galilaean region, 36 tying together such important cities as Sepphoris and Tiberias, as well as tying the area to its surrounding regions. As a result, Galilee was a center for import and export as well as general trade, resulting in a genuinely cosmopolitan flavor. ${ }^{37}$

Jesus was from Nazareth, and spent a sizable portion of his career in lower Galilee around the cities of Nazareth, Nain, Cana and Capernaum. Although Nazareth was a small village of only 1600 to 2000 in population, and it relied upon agriculture for its economic base (see Jn. 1:46, which might well be supported by what we know of the physical remains), it is not legitimate to think of Jesus as growing up in linguistic and cultural isolation. Nazareth was situated along a branch of and had a position overlooking one of the busiest trade routes in ancient Palestine, the Via Maris, which reached from Damascus to the Mediterranean. In fact this branch became more significant as Sepphoris grew in importance during Roman times. ${ }^{38}$ Capernaum, the village in which Jesus may have had a house (Mk. 2:1), though not a walled city according to the latest archaeological evidence, served as an important entrance to Gaulanitis (Golan Heights), with the means necessary for imposition of taxes and tolls (Mk. 2:14). With an estimated population of 12,000 to $15,000,39$ the village was part of a region that may have been one of the most densely populated in the Roman world. 40 The evidence from first-century construction witnesses to 'a community which very likely possessed greater financial means that [sic] is often associated with

${ }^{35}$ Hengel, 'Hellenization', 14-15; see also Fitzmyer, 'Languages of Palestine', 134-35; J.N. Sevenster, Do You Know Greek? How Much Greek could the First Jewish Christians have Known? (Leiden, Brill 1968) 96-97; Tcherikover, Hellenistic Civilization, 90-116.

${ }^{36}$ See Edwards, 'First Century Urban/Rural Relations', 171.

${ }^{37}$ See J.A. Overman, 'Who were the First Urban Christians? Urbanization in Galilee in the First Century', SBLSP 1988, 161.

${ }^{38}$ See Meyers and Strange, Archaeology, 43, 56-57.

${ }^{39}$ Meyers and Strange, Archaeology, 58.

${ }^{40} \mathrm{M}$. Broshi, 'The Population of Western Palestine in the Roman-Byzantine Period', BASOR 236 (1979) 3, 5. 
Capernaum.'41 It was a fishing village, with fishing apparently constituting its major source of economic gain. Nearby was Tiberias, a city built by Herod Antipas, where there was a population that was probably even more bilingual than Jerusalem (see Acts 6:1).

All of these factors are consistent with what we know of Jesus' own life and that of his followers. Matthew (Mt. 9:9; Lk. 5:27-28) or Levi (Mk. 2:13-14), the tax collector in Capernaum, would probably have known Greek in order to conduct his duties with the local taxpayers and the tetrarch Herod Antipas's officials.42 Many of Jesus' disciples were fishermen who worked the Sea of Galilee, including Simon Peter, Andrew, James and John. They almost assuredly would have needed to conduct in Greek much of their business of selling fish. 43 It is also worth noting that, of his disciples, Andrew and Philip had purely Greek names, and the names of Simon, Bartholomew and Thaddaeus may well have derived from Greek or gone easily into Greek. 44 This information helps to make sense of the scene in John's Gospel at 12:20-22, where Greeks asked of Philip, who was from Bethsaida (in Gaulanitis, across from Galilee), to see Jesus. He immediately went to Andrew, who was also reportedly from Bethsaida (Jn. 1:44). Jesus' being a carpenter or craftsman (Mk. 6:3), economically a middle level vocation, is consistent with the economic and cultural climate of the region, in which reciprocal trade was widespread. ${ }^{45}$ As Kee concludes, "This means that for Jesus to have conversed with inhabitants of cities in the Galilee, and especially of cities of the Decapolis and the Phoenician region,

41Overman, 'First Urban Christians', 162, citing from J. Strange, 'Review Article: The Capernaum and Herodium Publications', BASOR 226 (1977) 65-73.

42Schürer, History, 1.374.

43 See J.A.L. Lee, 'Some Features of the Speech of Jesus in Mark's Gospel', NovT 27 (1985) 1-36 esp. 6.

${ }^{44}$ Hengel, 'Hellenization', 16-17; idem, Pre-Christian Paul, 55-56. There is some dispute about Simon's name, since John's Gospel says that Jesus gave him the name Cephas (1:42), whereas Mark (3:16) and Luke (6:14) say that he was given the Greek name Peter, a masculine form of the word $\pi \varepsilon \dot{\tau} \rho \alpha$.

45See Edwards, 'First Century Urban/Rural Relations', 172-76; Meier, Marginal Jew, 278-85. 
he would have had to have known Greek, certainly at the conversational level.'46

\section{Epigraphic and Literary Evidence}

More impressive than what is known even of Galilee for establishing the probability that Jesus spoke Greek is the epigraphic and literary evidence for the widespread knowledge of Greek throughout Palestine including Galilee. It is not possible to discuss all of this evidence, but it is useful to cite significant findings as a means of establishing a plausible linguistic milieu for Jesus' possible use of Greek. The evidence can be usefully catalogued in terms of coins, papyri and literary texts, and inscriptions, including in the last especially funerary inscriptions. 47

Excluding several cities of the Decapolis, where they were minted much earlier, coins with Greek inscriptions were minted by the first century A.D. in the Galilaean city of Tiberias. In Palestine, the minting of coins in Greek had begun under the Hasmonaean ruler Alexander Jannaeus (103-76 B.C.), who issued bilingual coins with Greek and Hebrew, as did Mattathias Antigonus, the last Hasmonaean king, in 40-37 B.C. Under Herodian rule coins were minted exclusively in Greek, or in Greek and Latin under Agrippa II (A.D. 50-100). This includes those minted by Herod Antipas (4 B.C.-A.D. 39), who ruled Galilee during Jesus' lifetime. That these inscriptions were noticed and not strictly routine is made evident by the fact that during the two Jewish revolts (A.D. 66-70 and A.D. 132-35) Greek was not used on coins minted by the rebels. Nevertheless, as the evidence from the Greek Bar Kokhba letters indicates (see below), this does not mean that the rebels were not able to or did not use Greek. ${ }^{48}$ To the contrary, their

${ }^{46}$ H.C. Kee, 'Early Christianity in the Galilee: Reassessing the Evidence from the Gospels', in Levine (ed.), Galilee in Late Antiquity, 21.

47Loan words from Greek found themselves quite frequently into various Jewish documents, and Greek personal names were quite often found in Jewish writings. Apart from a literary context, it is difficult to know how much use of Greek these factors suggest. For a summary of some of the evidence, see Schürer, History, 2.53-54, 73-74; Lieberman, Greek in Jewish Palestine. It is noteworthy that this evidence is heaviest in the third and fourth centuries A.D.

48See Hengel, 'Hellenization', 8 and notes; Sevenster, Do You Know Greek? 122-26. 
use of Hebrew on the coins indicates that they were attempting to make a political statement that the populace would understand, not abandoning their linguistic ties to Greek.

Papyri and literary texts further establish the widespread use of Greek in Palestine. There have been a number of papyrus texts (including a number of fragments) found in Palestine written in Greek by Jews. ${ }^{49}$ The papyri of the Judaean Desert include a wide range and variety of artifacts, such as commercial transactions, fiduciary notes, contracts of marriage, and fragments of philosophical and literary texts, among others. ${ }^{50}$ Two Greek letters between Bar Kokhba and his commanders have been found among these. ${ }^{51}$ In one of these letters (both dated to the early second century A.D.), a Simon (?) Bar Kokhba, quite possibly the leader of the rebellion himself, writes to a Jonathan and a Masabala, stating that

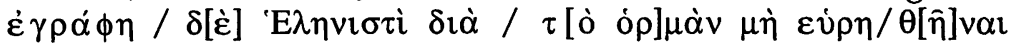

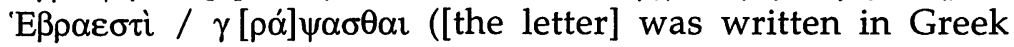
because the desire [?] was not found to write in 'Hebrew' $\left.{ }^{\prime 52}\right) .53$

${ }^{49}$ For literary texts written in Greek in Palestine but not by Jews, see Hengel, Judaism and Hellenism, 83-88. On the Zenon papyri as evidence of correspondence in Greek between Egypt and Palestine, see Hengel, Judaism and Hellenism, 7ff. and passim; Grabbe, Judaism, 1.172.

${ }^{50}$ See, e.g., P. Benoit, J.T. Milik and R. de Vaux, Les grottes de Murabba'at (Oxford, Clarendon Press 1961) nos. 89-107 (pp. 212-33), 108-112 (pp. 22438), 113 (239-40), 114-17 (pp. 240-58), 118-55 (pp. 258-67), 164 (pp. 275-77); N. Lewis, The Documents from the Bar Kokhba Period in the Cave of Letters: Greek Papyri (Jerusalem, Israel Exploration Society 1989); B. Lifshitz, 'The Greek Documents from Nahal Seelim and Nahal Mishmar', EIJ 11 (1961) 543-62; and Y. Yadin, Bar-Kokhba: The Rediscovery of the Legendary Hero of the Last Jewish Revolt against Imperial Rome (London, Weidenfeld and Nicolson 1971) 124-39, 172-83. See Schürer, History, 2.78-79; Fitzmyer, 'Languages of Palestine', 141, for summaries.

51See B. Lifshitz', 'Papyrus grecs du désert de Juda', Aeg 42 (1962) 240-56, now published as SB 8.9843, 9844 .

52On whether this refers to Aramaic or Hebrew, see Schürer, History, 2.28 n. 118.

${ }^{53}$ The original transcription by Lifshitz is followed by Fitzmyer, 'Languages of Palestine', 142, with questions noted on p. 143 n. 1 (in a text full of misspellings, the problem with the alpha rather than the eta in óp $\mu \alpha$ may not be that serious); Sevenster, Do You Know Greek? 172; and Hengel,

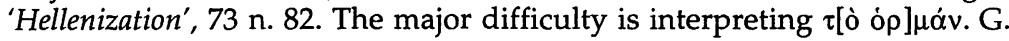
Howard and J.C. Shelton ('The Bar-Kokhba Letters and Palestinian Greek',

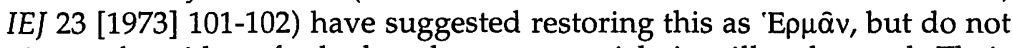
give a clear idea of whether the neuter article is still to be read. Their 
Even though these texts date to the early second century A.D., they are still useful for indicating the general linguistic climate of Palestine, witnessed to further by the discovery of a letter in Greek to a Judas at Masada, one of the last survivors of the first revolt, about the mundane topic of the supply of vegetables. ${ }^{54}$ As Fitzmyer states, 'at a time when the nationalist fever of the Jews must have been running high the leader of the revolt-or someone close to him, if Soumaios is not Simeon bar Kosibahfrankly prefers to write in Greek, or at least has to write in Greek. He does not find the o $\rho \mu \alpha$, "impulse, desire", to compose the letter $\dot{\varepsilon} \beta \alpha \ddot{i} \sigma \tau$. $^{\prime} 55$ The assumption is that the letter's recipients would have been able to read Greek to engage in the menial supply tasks asked of them. 56

So far as Jewish literature is concerned, there is also significant evidence of composition being done in Greek in Palestine by Jews for Jewish audiences. ${ }^{57}$ For example, the book of Daniel, besides using Greek names to refer in 3:5 to three musical instruments (lyre, harp and pipes [NIV]), and being composed in Hebrew and Aramaic, in its deuterocanonical form includes additional sections composed in Greek (Prayer of Azariah and the Song of the Three Children, Susanna, and Bel and the Dragon). ${ }^{58}$ Similarly, the six additions (107 verses) to

understanding is that there were a limited number in Bar Kokhba's ranks who wrote Greek. Y. Yadin has a plausible translation (he disputes that this letter is from the rebel leader), but it is difficult to see how he construes the Greek (Bar-Kokhba, 130, 132, cf. 132-33); similar in translation is Wise, 'Languages', 440: 'because no one was found to write it in 'Hebrew.'

54See Mussies, 'Greek in Palestine', 1058, citing the letter from Y. Yadin, 'The Excavation of Masada-1963/64: Preliminary Report', IEJ 15 (1965) 110. For a summary of the significant use of Greek at Masada, see now H.M. Cotton and J. Geiger, The Latin and Greek Documents, vol. 2 of Masada, The Y. Yadin Excavations 1963-65, Final Reports (Jerusalem, 1989) esp. 9-10, cited in Hengel, Pre-Christian Paul, 136 n. 259.

${ }^{55}$ Fitzmyer, 'Languages of Palestine', 143.

56See E.M. Smallwood, The Jews under Roman Rule: From Pompey to Diocletian (Leiden, Brill 1976) 452-53.

57See Hengel, 'Hellenization', 23-27; idem, Judaism and Hellenism, 83-102; and Schürer, History, 3,1.370-704 for literature composed in Greek, but not all of it composed in Palestine; and 3,2.705-808 for literature where the language of composition is ambiguous.

58See C.A. Evans, Noncanonical Writings and New Testament Interpretation (Peabody, MA, Hendrickson 1992) 14-15. 
Esther were composed in Greek and interposed in the Septuagintal version of the text. 59 Furthermore, two apocryphal books, 1 Esdras and 2 Maccabees, are thought likely to have been composed in Greek in Palestine. Worth noting as well is the fact that, although 2 Esdras and Judith were written in Hebrew, they survive virtually entirely or at least in significant part in Greek versions, quite possibly reflecting Jewish linguistic priorities for preservation of religious texts. Other writings worth mentioning for their probable Greek and Palestinian origins are the Testaments of the Twelve Patriarchs, especially the Testaments of Judah and Levi.60 A number of the books of the Septuagint were probably translated into Greek in Palestine as well, including 1 Maccabees, Esther (by one Lysimachus son of Ptolemaeus in 114 B.C.; probably in conjunction with the additions made in Greek), Chronicles, 2 Esdras (Ezra-Nehemiah), Song of Songs, Lamentations and Qoheleth, not to mention the continuing translation work of Theodotion and Aquila.61 Even though Jubilees was written in Hebrew it appears to have made extensive use of Greek geographical literature, requiring advanced knowledge of Greek by its author.62 Perhaps most striking of all is the fact that there have been a number of Greek Old Testament fragments from the minor prophets found in the Murabba'at caves, probably from a late first century A.D. scroll. 63

There are a number of other Jewish literary figures known to have written in Greek, although it is difficult to determine how many of them wrote in Palestine. Two of the most significant for which there is information are Justus of Tiberias and Flavius Josephus. Justus, the author of a history of the Jewish wars against Vespasian, is known only through what is said about him by Josephus, his rival, who respected

${ }^{59}$ Evans, Noncanonical Writings, 12.

60 See on this H.D. Slingerland, The Testaments of the Twelve Patriarchs: $A$ Critical History of Research (Missoula, MT, Scholars Press 1975).

61Hengel, Judaism and Hellenism, 101-102; idem, 'Hellenization', 24-25.

62Wise, 'Languages', 439.

${ }^{63} \mathrm{~B}$. Lifshitz, 'The Greek Documents from the Cave of Horror', IEJ 12 (1962) 201-207, which includes discussion of a non-biblical Greek papyrus fragment. A number of Greek documents have been found at Qumran as well, presumably written in Palestine, including a fragment of the apocryphal Letter of Jeremiah and a paraphrase of Exodus (see Hengel, Pre-Christian Paul, 61 and 136 n. 257). 
his knowledge of Greek, acquired in the Greek educational system of Tiberias (Life 34-42, 336-60; cf. also 65, 88, 175-78, 186, $279,390-93,410)$. Although there is some difference of opinion regarding Josephus's ability in Greek, from his own statements it seems that, although his pronunciation may not have been as good as he would have liked even after living in Rome, his grammatical ability was more than sufficient, certainly for day to day conversation, if not for highly literary purposes. The simple fact is that all of his publications have survived in Greek.64 Despite Josephus's statements deprecating his oral linguistic skills, he also claims to have acted as interpreter for the Roman general Titus (J.W. 5.360-61). Titus apparently spoke in Greek that was not sufficiently well understood by his listeners. Although the ability of Titus in Greek is attested by Suetonius (Divus Titus 3), it is not known whether the deficiency in this situation was with his listeners or with Titus. The urgency on Titus's part to make sure that the Jews understood exactly what he was saying may have influenced his desire to have Josephus, their kinsman, represent his position to them, especially those in Jerusalem. 65

Other Palestinian and/or Jewish authors worth mentioning are the anonymous Samaritan historiographer (Pseudo-Eupolemus) (Eusebius, Praep. Ev. 9.17 and 9.18.2) and

${ }^{64}$ There is debate about the sense in which Josephus's Antiquities and Jewish War are translations or original compositions in Greek. He claims that they are translations (Ant. 1.5; 10.218; J.W. 1.3; see also Ag. Ap. 1.50). Fitzmyer ('Languages of Palestine', 139) downplays the significance of this evidence for Josephus as a Palestinian historian, because he composed his writings in Rome. However, Rajak (Josephus, 51; followed by Wise, 'Languages', 440) concludes that Josephus's statements about his use of assistants indicates that he had never studied Greek formally while in Palestine, and consequently had never thought of it as much of an achievement. It must be kept in mind that there is a difference between the kind of Greek competence necessary to compose the Jewish War and that necessary to carry on conversation or transact business. It seems indisputable that Josephus had the latter competence while resident in Palestine.

65See Meier, Marginal Jew, 261 and notes; Fitzmyer, 'Languages of Palestine', 138; and Sevenster, Do You Know Greek? 62-65. Sevenster takes note of the varying Greek linguistic abilities of the Roman emperors, including the excellent Greek of Claudius and the halting Greek of Augustus (Suetonius, Divus Claudius 42, Divus Augustus 89), although he does not mention Titus's ability referred to by Suetonius. 
the Jewish historian Eupolemus (Eusebius, Praep. Ev. 9.26, 9.3034, 9.39; cf. Clement of Alexandria, Strom. 1.21),66 and Jason of Cyrene, summarized in 2 Maccabees. The Samaritan historiographer probably wrote in Palestine sometime between 200 and 165 B.C., Eupolemus sometime after 158/157 B.C., and Jason anywhere from soon after the death of Judas Maccabaeus to significantly later. ${ }^{67}$ Although the evidence is not strong, Hengel and others entertain the possibility that several writers or works usually identified with Alexandria may well have had their origins in Palestine, including the epic poet Philo, the poet Theodotus, Demetrius the Chronographer, the Tobiad Romance (Josephus, Ant. 12.154-236), and perhaps above all the grandson of Ben Sira, who translated his grandfather's work from Hebrew into Greek. Hengel concludes from these kinds of examples that it is not so simple to distinguish between the 'Jewish-Hellenistic' literature of the Diaspora and the "genuine Jewish" literature of Palestine. . there were connections in all directions, and a constant and lively interchange.'68 That Greek was used not only in the Diaspora but also in Palestine, even for composition by Jews of distinctly Jewish literature including much religious literature, indicates that Greek was an important and widely used language by a sizable portion of the Palestinian Jewish population.

The inscriptional evidence points in the same direction, although the quantity of material is simply too large to refer to in anything close to comprehensive terms. ${ }^{69}$ Nevertheless, there are a number of crucial texts that do point to the early and sustained, widespread use of Greek in Palestine and in

${ }^{66}$ See Schürer, History, 3,1.517-21, 528-31; J.H. Charlesworth, The Old Testament Pseudepigrapha (2 vols.; Garden City, NY, Doubleday 1985) 2.861-82. The anonymous Samaritan historiographer (Pseudo-Eupolemus) is, according to most recent scholarship, miscited by Eusebius as Eupolemus.

67See Hengel, Judaism and Hellenism, 83-96 esp. 88 and 92 with notes. Hengel also notes that the Greek Peripatetic Nicolaus of Damascus wrote his 144 books of universal history in Jerusalem while at the court of Herod.

68Hengel, 'Hellenization', 26.

${ }^{69}$ For convenient reference to the variety of material, see Hengel, 'Hellenization', 64; Fitzmyer, 'Languages of Palestine', 135-36 and passim; Meyers and Strange, Archaeology, 79-84; and Sevenster, Do You Know Greek? 115-38. The present paper connects a number of references in the secondary treatment, and adds several references to newer evidence. 
particular in Galilee.70 The reasonable assumption is that if these inscriptions were written in Greek they could be read or understood by a significant portion of the population, with their wide dissemination and various functions indicating that Greek was a primary language of communication for widespread and diverse segments of the populace. Several texts are fairly early, giving evidence of a longstanding and pervasive influence of Greek. Several religious inscriptions also bear witness to the presence of Greek religious practices and to widespread use of Greek language in their performance.

The most important inscriptions, however, include the following erected in conjunction with Jewish religious practices. The first, with two physical examples plus reference in Josephus (J.W. 5.193-94; 6.124-25; Ant. 15.417), is the inscription forbidding non-Jews to enter the inner courts of the temple in Jerusalem. ${ }^{71}$ Perhaps it is not surprising that this inscription is in Greek, since Jews are attempting to warn off non-Jews from entering the sacred precinct, although Kee notes that 'when the synagogue movement began to flourish and to take on architectural forms in the second century C.E., the inscriptions were in Greek, even in Jerusalem. ${ }^{72}$ It is just as

70 See, e.g., inscriptions from Joppa (217 B.C.) (printed in Sevenster, Do You Know Greek? 100; J. Kaplan, 'Jaffa's History Revealed by the Spade', Archaeology 17 [1964] 270-76), Hefzibah (Y.H. Landau, 'A Greek Inscription found near Hefzibah', IEJ 16 [1966] 54-70), Jamnia-on-the-Sea (B. Isaac, 'A Seleucid Inscription from Jamnia-on-the-Sea: Antiochus V Eupator and the Sidonians', IEJ 41 [1991] 132-44) and Acco-Ptolemais (SEG 19.904, cf. 20.413; Y.H. Landau, 'A Greek Inscription from Acre', IEJ 11 [1961] 118-26; cf. J. Schwartz, 'Note complémentaire [à propos d'une inscription grecque de St. Jean d'Acre]', IEJ 12 [1962] 135-36).

71OGIS 2.598; SEG 8.169; CIJ 2.1400. Reprinted many times, this inscription is conveniently found in A. Deissmann, Light from the Ancient East (repr. Grand Rapids, Eerdmans 1978) 80; J. Finegan, The Archaeology of the New Testament: The Life of Jesus and the Beginning of the Early Church (Princeton, Princeton University Press 1969) 119-20, who prints both versions; Schürer, History, 2.222 n. 85; and now P. Segal, 'The Penalty of the Warning Inscription from the Temple of Jerusalem', IEJ 39 (1989) 79-84. Fully $40 \%$ of the inscriptions found in Jerusalem are in Greek. It was not uncommon for inscriptions to be bilingual with Greek and Latin used outside of Palestine during the Roman period. Although Josephus cites a Latin version of this temple inscription, the Latin inscription itself has not been found.

72Kee, 'Early Christianity in the Galilee', 20. 
likely, therefore, that Greek was one of the major languages of Jewish life, even in its religious institutions, as the two following inscriptions also bear witness. The second inscription is one honoring a man named Paris who paid for a stone pavement on or around the Temple. This inscription probably dates to the time of Herod the Great. ${ }^{73}$ That the donor was from Rhodes may have influenced the choice of Greek for the inscription, although the nature of the inscription would indicate that its erection was for the benefit of those in Jerusalem who could read it or have it read to them at least as much as for the benefactor. Third is the so-called Theodotus inscription, found outside of Jerusalem. It probably dates to the first century, before A.D. 70.74 The significance of this Greek inscription is that it bears witness to one Theodotus, son of Bettenos, a priest and head of the synagogue, who was the son and grandson of the head of the synagogue, and who himself built a synagogue for the reading of the law and study of the commandments. This thoroughly Jewish man is highly commemorated in Greek. A fourth inscription is a unilingual Greek decree of a Caesar forbidding the violation of sepulchers. This inscription most likely dates to the first century A.D., although this is not agreed upon by all, and it may well have been erected in Galilee (Nazareth), although there is dispute about this also. Although perhaps not a formal decree but a response by a Caesar to a question regarding these sepulchral violations, it can be reasonably assumed that it would only have had significance if those who read it (or had it read to them) were able to understand Greek. ${ }^{75}$ The last example is a first or second century A.D. dedicatory inscription upon a column from Capernaum. ${ }^{76}$ In all, this inscriptional evidence confirms the significant and widespread use of Greek

73B. Isaac, 'A Donation for Herod's Temple in Jerusalem', IEJ 33 (1983) 8692. See Hengel, 'Hellenization', 66 n. 34.

74SEG 8.170; CIJ 2.1404. See Hengel, Between Jesus and Paul, 148 n. 119; Sevenster, Do You Know Greek? 131-32. Most synagogue inscriptions date to the second and third centuries A.D. and consequently do not add anything to what has already been said here.

75SEG 8.13. See Sevenster, Do You Know Greek? 117-21; F.F. Bruce, New Testament History (Garden City, NY, Doubleday 1971) 300-303. The Greek may at several points indicate that it is a translation of Latin. Contra Meier, Marginal Jew, 256, with reference to the Pilate inscription.

76SEG 8.4, cf. 17.774. See Fitzmyer, 'Languages of Palestine', 140. 
throughout Palestine, even in conjunction with Jewish religious practices.

Concerning inscriptional evidence from burial sites, Leon has said that the best indicator of the language of the common people is the sepulchral inscriptions, 77 and the evidence certainly indicates a widespread and constant use of Greek in Palestine, including especially Galilee. To put the evidence from funerary inscriptions into its proper context, 78 it is worth noting that, according to the latest statistics on published inscriptions, $68 \%$ of all of the ancient Jewish inscriptions from the Mediterranean world are in Greek (70\% if one counts as Greek bilingual inscriptions with Greek as one of the languages). As van der Horst observes, 'The first impression one gains from these data is that Greek was the language of the great majority among the Jews in the Imperial period, probably of more than two-thirds of them. ${ }^{79}$ In

77H.J. Leon, The Jews of Ancient Rome (Philadelphia, Jewish Publication Society of America 1960) 75-76, at the beginning of his discussion of language. Most recent analysts of the funerary inscriptions would endorse this position; contra Meier, Marginal Jew, 289 n. 10. Speculation whether the language used was actually that of the deceased, his or her relatives or the stone mason is futile and largely beside the point, since the use of Greek by Jews in such a context indicates its significance in Palestine.

${ }^{78}$ For convenient reference to the funerary inscriptions, see now P.W. van der Horst, Ancient Jewish Epitaphs: An Introductory Survey of a Millennium of Jewish Funerary Epigraphy (300 BCE-700 CE) (Kampen, Kok Pharaos 1991), who analyses the linguistic character of the Greek; idem, 'Das Neue Testament und die jüdischen Grabinschriften aus hellenistisch-römischer Zeit', BZ 36 (1992) 161-78; idem, 'Jewish Funerary Inscriptions-Most are in Greek', BAR $18(5 ; 1992)$ 46-57, a summary of his work.

${ }^{79}$ Van der Horst, Ancient Jewish Epitaphs, 22, cf. 129-32. Regional variation confirms this opinion, in van der Horst's mind. For example, of the Jewish funerary inscriptions from Rome, $78 \%$ are in Greek but only $1 \%$ are in Hebrew or Aramaic (21\% are in Latin). 'This is surprising, the more so in view of the fact that in the vast majority of Roman tomb-inscriptions Latin is the predominant language in those of other orientals, especially the numerous Syrians in Rome' (p. 22). From this evidence, he concludes that 'One should not assume that they used Greek only on their tombstones as a kind of sacred language (comparable to the use of Latin in later Christian funerary epigraphy in the West), for their sacred language remained Hebrew, as is witnessed by the many Greek and Latin inscriptions ending in the single Hebrew word shalom, or the expressions shalom 'al mishkavo or shalom 'al Yisra'el' (p. 23). The Hebrew is often transliterated into Greek: e.g. CIJ 2.1034, 1036 and 1037, 1038, 1113. 
Palestine in particular, the situation is similar. For example, at the city of Beth She'arim, in western Galilee, a set of catacombs and tombs were used as burial sites from the first to the sixth centuries A.D. At this Jewish site, where many significant Jewish religious figures, including rabbis, are buried, the earliest catacombs (first to second centuries A.D.) are all in Greek. In all, up to $80 \%$ of the Beth She'arim catacombs are in Greek, some of it quite colloquial and reflecting aphoristic Greek thinking. ${ }^{80}$ Even in Jerusalem, probably the most linguistically Semitic of the Jewish cities, the number of epitaphs in Greek is approximately equal to the number in Semitic languages. 81 Taking all of the Palestinian funerary inscriptions into account, it is estimated that 55 to $60 \%$ of all of them are in Greek. These data are not to be underestimated. Since Hebrew may well still have been the predominant Jewish religious language, at least of the devout, it is easy to account for the Semitic inscriptions. But it is less easy to account for the Greek ones unless Greek was simply a commonly used language by many Jews. The logical conclusion is that the statistics for Greek may well be a conservative estimate of the percentage of people that spoke Greek in the Jewish population of Galilee and even of Palestine. At the most private and final moments when a loved one was finally to be laid to rest, in the majority of instances, Jews chose Greek as the language in which to memorialize their deceased. Greek was apparently that dominant, that in the majority of instances it took precedence over the Jewish sacred language, even at a moment of highly personal and religious significance. As van der Horst concludes, 'If even rabbis and their families phrased their

${ }^{80}$ Meyers and Strange, Archaeology, 86, 101. See Sevenster, Do You Know Greek? 138-42, who concludes, 'If Greek is used on the majority of the tombstones and ossuaries, this is a strong indication that Greek was mainly spoken in that region and that consequently the Semitic language had become the secondary one for many people, though still used as a sacred language in the funerary inscriptions.'

81See M. Avi-Yonah (ed.), Encyclopedia of Archaeological Excavations in the Holy Land (Englewood-Cliffs, NJ, Prentice-Hall 1976) 2.629-41; N. Avigad, 'A Depository of Inscribed Ossuaries in the Kidron Valley', IEJ 12 (1962) 112. In nearby Jericho, the tomb of the 'Goliath' family has over half of its epitaphs in Greek, much of it in better-formed letters than the Aramaic. See R. Hachlili, 'The Goliath Family in Jericho: Funerary Inscriptions from a First Century A.D. Jewish Monumental Tomb', BASOR 235 (1979) 31-65. 
epitaphs in Greek, there is only one natural explanation for that phenomenon: Greek was the language of their daily life.' 82

\section{Jesus' Use of Greek and the New Testament Evidence}

In the light of this accumulated evidence, which is overwhelming when compared to the equivalent Aramaic evidence, it is surprising that many scholars have not given more consideration to the hypothesis that Jesus spoke and even possibly taught in Greek, and furthermore that there is a possibility if not a likelihood that we have some of the actual words of Jesus recorded in the Gospels. ${ }^{83}$ In fact, it is almost as if there is an inherent resistance to this hypothesis. It is found in several forms. For example, some scholars attempt to trivialize the claim by differentiating between the ordinary spoken words of Jesus and his teaching. 84 The point being argued for here is that, when the evidence is laid out, there is a presumption in favor of the hypothesis that at the least Jesus knew and in fact spoke Greek (he had productive linguistic competence), whether or not he could carry on extensive discourse. 85 To some extent this makes it unnecessary to differentiate between ordinary speaking and teaching. To be able to speak in Greek would imply at least the possibility of teaching in Greek but it would not necessarily require it on account of circumstances, such as his level of competence, the composition of his audience, the subject matter, or the particular context. It must be recognized, of course, that the very nature of the compositional process of the Gospels makes it extremely difficult to know which passages may reflect the words of Jesus. For instance, since the Gospels are in Greek,

82Van der Horst, Ancient Jewish Epitaphs, 24.

${ }^{83}$ See Argyle, 'Did Jesus Speak Greek?' 93; Gundry, 'Language Milieu', 408.

${ }^{84}$ Fitzmyer, 'Did Jesus Speak Greek?' 62. But cf. Sevenster, Do You Know Greek? 27.

85It is outside the parameters of this paper to raise the question of whether Jesus could read or write Greek. It is difficult to define what exactly constitutes literacy, but it has been recently estimated that in the hellenistic world twenty to thirty per cent of males were literate, or could read and write (W.V. Harris, Ancient Literacy [Cambridge, MA, Harvard University Press 1989] 16-46 esp. 41). Meier (Marginal Jew, 268-78) thinks that Jesus was literate in Semitic languages. See Porter, 'Introduction', 3637. 
one must devise a means to differentiate the Greek words of Jesus from the Greek wording of the author. Lee has made us aware of the fact that the Greek used by Jesus in Mark's Gospel at points conforms to a higher register than the Greek of the narrative itself. One could speculate that this captures the actual language of Jesus, but it may also simply reflect an attempt by the author to ensure that due respect and reverence are given to Jesus even in the language that he uses. 86

Nevertheless, I believe that, first, it can be firmly established that Jesus did speak Greek and that we do indeed have some of his actual words. Once this has been established, then it can be seen that there are several other passages that may well record the words of Jesus, including the scene in Caesarea Philippi, when Jesus endorses Peter's confession that he is the Christ. ${ }^{87}$ In several of these contexts Jesus is recorded as speaking to others who plausibly did not speak a Semitic language, and where no translator or interpreter is indicated (see also Mt. 8:28-34; Mk. 5:1-20; Lk. 8:26-39). Interpreters or translators are specified by other writers during this period (e.g. Josephus, Ag. Ap. 1.50-51; J.W. 5.361; 6.96, 129, 327; all of these in Jerusalem). Whereas the Gospel writers may have failed to do so, this is not consistent with how the Gospels often

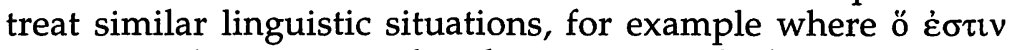
$\mu \varepsilon \theta \varepsilon \rho \mu \eta v \varepsilon v o ́ \mu \varepsilon v o v$ or similar phrases are used when Aramaic is cited and a translation in Greek is included (e.g. Mt. 1:23; Mk. 5:41; 15:22, 34; Jn. 1:38, 41, 42; 9:7; cf. also Acts 4:36; 9:36; Heb. $7: 2)$.

\section{Mark 15:2-5//Matthew 27:11-14//Luke 23:2-5//John 18:29-38}

The first and most important example, and the one that sets the tenor for the subsequent treatment of passages, is Jesus'

${ }^{86} \mathrm{Lee}$, 'Some Features of the Speech of Jesus', 1-8.

${ }^{87}$ But see Meier, Marginal Jew, 294-95 and n. 40; and Fitzmyer, 'Did Jesus Speak Greek?' 60-61, among others, who question these contexts. Other instances where Jesus may have spoken Greek have been suggested, including the Sermon on the Mount (Mt. 5-7; cf. also Lk. 6), and Jesus' conversations with the Samaritan woman (John 4) and with Mary Magdalene (John 20) (Roberts, Greek, 145-57), the use of żлıviбıs in the

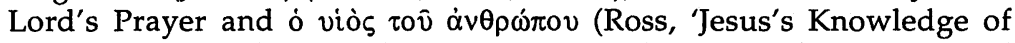
Greek', 43-46), and vंлокрı and the Aramaic Theory', ExpT 75 [1963-64] 113-14; idem, 'Greek among the Jews', 89). 
trial before Pilate (Mk. 15:2-5; Mt. 27:11-14; Lk. 23:2-5; Jn. 18:2938; cf. 1 Tim. 6:13). It is highly unlikely that Pilate, the prefect assigned to this remote posting in the Roman empire, would have known any Semitic language. No translator or interpreter is mentioned for the conversation that occurs between Jesus and Pilate, making it unlikely that Latin or Aramaic was used. In fact, the pace of the narrative, in which conversation is held between not only Pilate and Jesus but Pilate and the Jewish leaders, Pilate and the crowd, and the Jewish leaders and the crowd, argues against an interpreter intervening. ${ }^{88}$ It is most likely, therefore, that Jesus spoke to Pilate in Greek. ${ }^{89}$ In fact, there is the probability that all of the conversation, including that of Pilate with the Jewish leaders and the crowd (and possibly that of the Jewish leaders and the crowd?), took place in Greek. But do we have the actual words spoken? I believe that we may well have at least some of these words, confirmed by the criteria of multiple attestation and dissimilarity. There are apparently two separate accounts of Jesus' trial in the Synoptic Gospels and John. ${ }^{90}$ There is little overlap in detail or wording, except at two places: John 18:33-34 and 37, and Mark 15:2, Matthew 27:11, Luke 23:3, and only in a few words spoken by Pilate and Jesus. The narrative surrounding these few select words is clearly dependent upon Mark in Matthew and Luke, but this same narrative shares virtually no wording between the Synoptic accounts and John's Gospel except in the question posed by Pilate and in Jesus' response. Pilate asks Jesus, $\sigma \dot{v} \varepsilon \hat{i} \dot{o}$

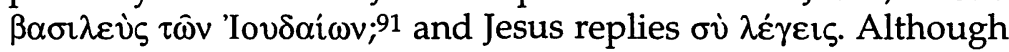

88Roberts, Greek, 161-62.

${ }^{89}$ As Dalman himself recognizes (Jesus-Jeshua, 5).

90So most commentators, including R.E. Brown (The Gospel according to John [2 vols.; Garden City, NY, Doubleday 1970] 2.861) and R. Schnackenburg (The Gospel according to St. John [3 vols.; New York, Crossroad 1982] 3.247-48); contra C.K. Barrett, The Gospel according to St. John (2nd ed.; Philadelphia, Westminster 1978) 536, who thinks it is an expansion of Mark.

91These same words are found in the titulus placed above the cross (see Mt. 27:37; Mk. 15:26; Lk. 23:38; John 19:19). C.E.B. Cranfield (Mark [Cambridge, Cambridge University Press 1972] 457) notes that, whereas

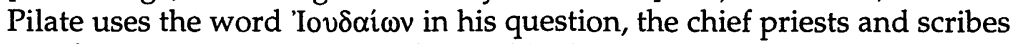
use the more proper 'I $\sigma \rho \alpha \dot{\eta} \lambda$ (Mk. 15:32; Mt. 27:42; but cf. Lk. 23:37). See Josephus, Ant. 15.373, 16.311 for the title 'king of the Jews' (cf. 14.36, for similar language on a Latin or Greek inscription), showing the currency of 
the Synoptic Gospels allow this reluctant, affirmative answer to stand as Jesus' only words of response, in Jesus' extended and delayed reply John embellishes the account, wrapping around these two words a complex answer that explicates Jesus' kingship. The words $\sigma \dot{v} \lambda \dot{\varepsilon} \gamma \varepsilon \iota \varsigma$ appear nowhere else in the Synoptic Gospels, revealing that they are not a part of any of the Gospels' redactional tendency. The same two words do appear in John 8:33, 52, 9:17 and 14:9,92 but in these Johannine instances they are used not in a statement but only in a question, and all of these but 14:9 not on the lips of Jesus. The infrequency of this wording in the Synoptic Gospels (criterion of dissimilarity), as well as the way in which it is used in John's apparently independent account (criterion of multiple attestation), indicates that not only is there a likelihood that we have the Greek wording of Pilate's question to Jesus, 93 but in these two words we may well have Jesus' actual response. 94

\section{Mark 7:25-30; John 12:20-28; Matthew 8:5-13//Luke 7:2-10}

Firmly establishing the high probability that Jesus spoke Greek and that we have his very words opens up the possibility that other passages may also record Jesus' words. Of these instances, the first example of a passage in which Jesus may well have spoken Greek is Mark 7:25-30, when Jesus travels to the area of Tyre. $95 \mathrm{~A}$ woman with a daughter possessed by an evil spirit hears of his presence there and begs for Jesus' help. The woman is called in Mark's Gospel a 'E $\lambda \lambda \eta v i \varsigma$, a

this title in Palestine of that time (see J. Fitzmyer, Luke X-XXIV [Garden City, NY, Doubleday 1985] 1475).

92 These eight are the only instances in the entire New Testament. The plural $\dot{v} \mu \varepsilon i \varsigma$ $\lambda \dot{\varepsilon} \gamma \varepsilon \tau \varepsilon$ is used in Luke 22:70, its only use in the Synoptic Gospels. $\sigma \dot{v}$ ei $i \pi \varsigma_{\varsigma}$ appears only at Mt. 26:25, 64.

93A.H. McNeile (The Gospel according to St. Matthew [London, Macmillan 1957] 409) contends that Pilate's question is unexpected, except in Luke's Gospel, with no foundation for its being asked. This supports the hypothesis of the words being authentic. See also Barrett, John, 536 .

${ }^{94}$ See also Birkeland, Language of Jesus, 17. For the similarities of Pilate's interrogation of Jesus with what might have been expected from a Roman official at the time, see A.N. Sherwin-White, Roman Society and Roman Law in the New Testament (repr. Grand Rapids, Eerdmans 1978) 24-47.

95Many good early manuscripts read 'Tyre and Sidon' (a A B $f^{1,13}$ Majority text $p c$ ), but this is probably assimilation to Mk. 7:31 and Mt. 15:21. UBSGNT ${ }^{3}$ gives the reading 'Tyre' an A rating. 
$\Sigma$ vpoфotvíkı $\sigma \sigma \alpha$ by birth, i.e. a gentile (7:26). ${ }^{96}$ Even though the indigenous language of the area was Semitic, this area had long been under hellenistic influence (and antagonistic to the Jews; see Josephus, Ag. Ap. 1.69-72) and evidenced widespread use of Greek, as has been noted above. The description of the woman in the Gospel makes sure that the reader knows that the woman was a Greek-speaker despite her birth. Otherwise the reference is gratuitous. There is no indication of an interpreter being present. Although there is not sufficient corroborative evidence to know whether Jesus' words here are his own, the context clearly indicates the likelihood that Jesus spoke in Greek to the gentile woman, and that his discussion may record his actual words. 97

A further incident is John 12:20-28 (or -36), already

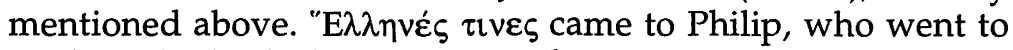
Andrew, both of whom have Greek names, and who both went to Jesus. The use of "E $\lambda \lambda \eta v \varepsilon \varsigma$ here almost certainly refers to Greek-speaking gentiles (cf. Mk. 7:26 above), whether or not they came from Greece (as they almost assuredly did not), and does not mean Greek-speaking Jews, as the comparative terminology of Acts 6:1 indicates. ${ }^{98}$ These people would probably have been gentiles from one of the Greek-speaking areas, quite possibly of northern Palestine in the area of Galilee or the Decapolis, since Philip and Andrew (and Peter; cf. Jn. 1:44) were reportedly from Bethsaida. ${ }^{99}$ Dalman was of the

965ee R.H. Gundry, Mark: A Commentary on his Apology for the Cross (Grand Rapids: Eerdmans 1993) 379-80. The Syrophoenicians (as distinguished from other Phoenician groups) can probably be identified with what are traditionally called the Canaanites. This indicates that the parallel in Mt. 15:21-28 probably reflects the same incident. It is in keeping with Matthew's character as a more Jewish Gospel that he does not emphasize the gentile and Greek characteristics of the woman. See H.B. Sweet, The Gospel according to Mark (London, Macmillan 1898) 148; C.S. Mann, Mark (Garden City, NY, Doubleday 1986) 320; R. Guelich, Mark 1:1-8:26 (Dallas, Word 1989) 385; G. Schwarz, ' $\Sigma$ YPOФOINIKI $\Sigma \Sigma A-X A N A N A I A$ (Markus 7.26/Matthäus 15.22)', NTS 30 (1984) 626-28.

97See esp. Gundry, Mark, 375; G. Theissen, 'Lokal- und Sozialkolorit in der Geschichte von der syrophönischen Frau (Mk 7:24-30)', ZNW 75 (1984) 202-225 esp. 206-213; F. Dufton, 'The Syrophoenician Woman and her Dogs', ExpT 100 (1988-89) 417.

98Barrett, John, 421.

${ }^{99}$ Bethsaida, in Gaulanitis and not technically in Galilee, was quite possibly referred to as being in Galilee, especially after A.D. 66-70. 
opinion that the Greek-speakers went to the disciples because Jesus was not identified with the Greek-speaking Jews. ${ }^{100}$ The narrative does not prove this point, however, since there could have been a variety of reasons why they would have not wanted to approach Jesus directly, including perhaps Jesus' status. Jesus' response gives no indication that he could not communicate with them. ${ }^{101}$ If the incident is historical, 102 then there is the presumption that Jesus could well have addressed at least some of his words to them in Greek.103

The third example is Jesus' meeting in Capernaum with the centurion (Mt. 8:5-13; Lk. 7:2-10; he is probably referred to in Jn. 4:46-53 as a $\beta \alpha \sigma \imath \lambda \imath$ kó $\varsigma$, perhaps a commander of a troop of soldiers serving under Herod Antipas). ${ }^{104}$ This $Q$ passage has been independently redacted by Matthew and Luke, with Luke including Jewish emissaries to represent the centurion's cause to Jesus, which would possibly exclude this example if Luke's version is original (commentators are divided on which version depicts what actually happened, although the tendency is to see Matthew's as primary). ${ }^{105}$ Nevertheless, several common points emerge from the accounts. They both retain Jesus'

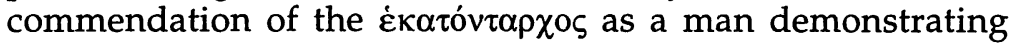
faith not found in Israel, the presumption being that he is seen by Matthew and Luke as a gentile centurion, and presumably a Greek speaker. Even though we probably have both the $Q$ version and the Johannine version of this incident, 106 there is no common dialogue to compare for authentication, even though

Andrew and Philip may have had Greek names, even if they were Jews. See Barrett, John, 183.

${ }^{100}$ Dalman, Jesus-Jeshua, 5.

${ }^{101}$ See Sevenster, Do You Know Greek? 25-26.

${ }^{102}$ For a summary of the issues, see J. Beutler, 'Greeks Come to See Jesus (John 12,20f)', Bib 71 (1990) 333-35.

${ }^{103}$ See John 7:35-36, where the Jews' response indicates that they thought that Jesus could go into the Diaspora, i.e. to a Greek or gentile populated area, presumably with the ability to teach them in Greek.

${ }_{104}$ See R.H. Gundry, Matthew: A Commentary on his Literary and Theological Art (Grand Rapids, Eerdmans 1982) 141; J.A.G. Haslam, 'The Centurion at Capernaum: Luke 7:1-10', ExpT 96 (1984-85) 109-110.

105See M.D. Goulder, Luke: A New Paradigm (2 vols.; Sheffield, JSOT Press 1989) $1.379-80$.

106 See W.D. Davies and D.C. Allison, A Critical and Exegetical Commentary on the Gospel according to Saint Matthew (3 vols.; Edinburgh, Clark 1988-) 2.17-18. 
there is the likelihood that Jesus would have spoken to the centurion in Greek, if he spoke directly to him.

\section{Matthew 16:13-20//Mark 8:27-30//Luke 9.18-21}

The final example for consideration is Jesus' discussion with his disciples at Caesarea Philippi (Mt. 16:13-20; Mk. 8:27-30; Lk. 9:18-21), although the teaching material attributed to Jesus in this incident is found only in Matthew's Gospel. Although the certainty of the incident itself or of the very words being those of Jesus is not as great as with the incidents recorded above, a number of features of the language in its Matthaean version ${ }^{107}$ point to this being material formulated early on in Greek. It might at first seem strange that Jesus and his followers would speak Greek and not Aramaic in this private conversation, unless the full force of the evidence above is taken into consideration. In conjunction with what we know of Jesus' linguistic ability and the location to the south of Galilee in which the incident occurred, there is a reasonable likelihoodif not probability-that this pericope records the Greek words of Jesus.

The first line of support comes from the location itself. The incident occurred in the region (Matthew) or villages (Mark) of Caesarea Philippi. Caesarea Philippi, located in Gaulanitis in the far north of Palestine, was a gentile city long before its hellenistic refounding by Herod the Great, who built a temple in honor of Caesar Augustus, and its rebuilding and renaming from Panias (so-called after its grotto to Pan) by Herod Philip. 108 It is as likely a location for the use of Greek language as almost any other in Palestine. Of course, this likelihood does not determine that Jesus must have spoken in Greek, but it does not make the use of Greek foreign to one who had such capability, as shown above.

A second factor is with regards to Synoptic priorities. Although the majority of scholars usually endorse Markan priority in recounting this incident, this is not entirely certain, even though many would recognize the essential historicity of

107For more detailed discussion, see S.E. Porter, 'Vague Verbs, Periphrastics, and Matt 16:19', Filología Neotestamentaria $1(2 ; 1988)$ 155-73. ${ }^{108} \mathrm{On}$ the history of Caesarea Philippi, including some of its hellenistic elements, see G. Dalman, Sacred Sites and Ways: Studies in the Topography of the Gospels (trans. P.P. Levertoff; London, SPCK 1935) 195-207. 
the event. ${ }^{109}$ Discussion of the major features of the Matthaean account will serve to suggest if not Matthaean priority at least Matthaean independence, and the probability that these words were early formulated in Greek, quite possibly by Jesus himself.

One of the most important features of Jesus' words to Peter after his confession of Jesus as the Christ, the Son of the living God (only Matthew has the entire title), is Jesus' wordplay revolving around Peter's name. Although there is debate

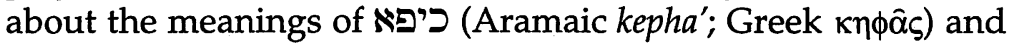
$\pi \varepsilon$ ' $\rho \varsigma_{1}, 110$ the major issue revolves around whether the apparent word-play in the biblical text works best in Aramaic or in Greek alone.111 In Aramaic, Jesus would apparently have said, 'You are כיפא (rock) and upon this כיפא (rock) I intend to build my church.' It cannot be determined whether this was the first time Jesus addressed the issue of Peter's name, an issue raised elsewhere in the New Testament (e.g. Jn. 1:42; cf. 1 Cor.

${ }^{109}$ For those who dispute the historical veracity of the account, among others see R. Bultmann, The History of the Synoptic Tradition (rev. ed.; Oxford, Blackwell 1972) 138-40, 258-59, who tries to argue that the placereference belongs to the previous pericope; T.W. Manson, The Sayings of Jesus (London, SCM 1947) 201-205; R.E. Brown et al. (ed.), Peter in the New Testament (London, Geoffrey Chapman 1973) 83-101; B.P. Robinson, 'Peter and his Successors: Tradition and Redaction in Matt 16:17-19', JSNT 21 (1984) 86-87; J. Lambrecht, "Du bist Petrus"-Mt 16,16-19 und das Papsttum', SNTU 11 (1987) 5-32; cf. also M. Wilcox, 'Peter and the Rock: A Fresh Look at Matt 16:17-19', NTS 22 (1976) 73-74. Significant defenses of the authenticity of the passage are found in O. Cullmann, Peter: Disciple, Apostle, Martyr: A Historical and Theological Study [2nd ed.; London, SCM 1962) 176-217 esp. 190-191; B.F. Meyer, The Aims of Jesus (London, SCM 1979) 185-97.

${ }^{110}$ See J.A. Fitzmyer, 'Aramaic Kepha' and Peter's Name in the New Testament', in Text and Interpretation: Studies in the New Testament Presented to M. Black (ed. E. Best and R.McL. Wilson; Cambridge, Cambridge University Press 1979) 121-32.

111Cullmann (Peter, 191-93; idem, ' $\pi \varepsilon \dot{\tau} \rho \varsigma^{\prime}$ ', TDNT 6 [1968]; idem, ' $\pi \varepsilon \dot{\tau \rho \alpha ', ~}$ TDNT 6 [1968] 98-99) claims that the pun cannot work in Greek, while P. Lampe ('Das Spiel mit dem Petrusnamen-Matt. XVI.18', NTS 25 [1979] 227-45) and Hughes ('Language Spoken by Jesus', 141), followed by Gundry (Matthew, 333-34), claim that the pun works only in Greek. B.D. Chilton (Targumic Approaches to the Gospels: Essays in the Mutual Definition of Judaism and Christianity [Lanham, University Press of America 1986] 80 n. 31) claims that PTR, however, is an Aramaic term borrowed from Greek which appears in Aramaic with the meaning 'foundation.' 
$1: 12 ; 3: 22 ; 9: 5 ; 15: 5 ;$ Gal. 1:18; 2:9, 11, 14). While some scholars would argue that the word-play does not work well in Greek because two different Greek words are used rather than simply citing the statement on the basis of an Aramaic original, the use of cognate forms (possibly indicating paronomasia) points to the importance of the Greek formulation. According to this reasoning, $\pi \varepsilon \dot{\varepsilon} \tau \rho \varsigma$, a masculine noun, and the name given to Simon (Mk. 3:16; Lk. 6:14), is frequently in Greek literature understood to mean a simple 'stone' (Sophocles, Oed. Col. 1595; Euripides, Her. 1002). $112 \pi \varepsilon \dot{\varepsilon} \alpha \alpha$, a feminine noun and inappropriate as a man's name, often is used to refer to a mass of rock (Euripides, Ion 936). Jesus thus says, 'You are $\pi \dot{\tau} \tau \rho o \varsigma$ (a name for an individual male and a single stone) and upon this $\pi \varepsilon \dot{\tau} \rho \alpha$ (firm foundation of stone) I intend to build my church.' This accounts well for the alternation in Greek words, unnecessary if it merely translates the same Aramaic word, and it accommodates general Greek usage of the two words as well.113 It might be objected that this word-play is to be attributed to the Matthaean redactor. The fact that there are no similar scenes in Matthew, in which there is a similar kind of play on a disciple's name, indicates that it is not part of Matthew's redactional tendency, and therefore could well be attributed to earlier tradition, quite possibly even to Jesus himself.

Virtually every discussion of Matthew 16:17-19 seems to mention sooner or later the periphrastic constructions in $\mathrm{v}$. 19, found elsewhere in the New Testament only in Matthew 18:18 and Hebrews 2:13. Debate over this future perfect passive periphrastic has not disputed its Greek origin or formulation, 114 but has disputed its meaning and translation. Rather than as the equivalent of an English future perfect passive (where a future event is the result of a first event occurring before the time of speaking or writing, i.e. 'shall have been

112See H.G. Liddell and R. Scott, A Greek-English Lexicon (ed. H.S. Jones with R. McKenzie; Oxford, Clarendon Press 1968) s.v.

${ }^{113}$ Cf. Lampe, 'Das Spiel mit dem Petrus-Namen', 242-45, who concludes similarly, although on the basis of a folk etymology by early Christians. The question regarding whether Jesus intends to found his church upon Peter himself is outside the bounds of this paper. On the issue see now C.C. Caragounis, Peter and the Rock (Berlin, de Gruyter 1990).

${ }^{114}$ See Porter, Verbal Aspect, 471 n. 35, 473-74, for extra-biblical Greek parallels. 
bound/loosed'), 115 or as a statement of once for all action, 116 or as a nonperiphrastic use of the adjectival participle,117 a more accurate understanding of the periphrastic construction appreciates the stative rather than temporal verbal aspect of the perfect participle, and temporal reference based on the discourse structure rather than the simple use of the future form of the auxiliary verb. ${ }^{118}$ (A translational gloss: 'whatever you might bind upon the earth [if such a binding event were to occur], this is projected as being in a state of boundness in heaven; and whatever you might loose upon the earth shall be in a state of loosedness in heaven'.) Again it might be argued that this complex conditional-like periphrastic might be the work of the Matthaean redactor. As mentioned above, however, apart from Matthew 18:18, found in a similar context, there is no other use of this structure in Matthew's Gospel or in any of the other Gospels, denying this as a Matthaean redactional tendency. The closest conceptual parallel is John 20:23, which does not use the periphrastic construction but the simplex verb form. This provides further evidence that this passage was formulated early in Greek, quite possibly by Jesus himself.

The third and final major textual feature to discuss is the use of the word $\dot{\varepsilon} \kappa \kappa \lambda \eta \sigma i \alpha$. The use here of $\dot{\varepsilon} \kappa \kappa \lambda \eta \sigma i \alpha$, found in the Gospels only here and at Matthew 18:17, has often been cited as clear indication either of a later formulation of this

115J.R. Mantey, 'The Mistranslation of the Perfect Tense in John 20:23, Matth 16:19, and Matth 18:18', JBL 58 (1939) 243-49; idem, 'Evidence that the Perfect Tense in John 20:23 and Matt 16:19 is Mistranslated', JETS 16 (1973) 129-38.

116H.J. Cadbury, 'The Meaning of John 20:23, Matt 16:19, and Matt 18:18', JBL 58 (1939) 251-54.

${ }^{117} \mathrm{~N}$. Turner, Grammatical Insights into the New Testament (Edinburgh, Clark 1965) 80-82; idem, Syntax, vol. 3 of A Grammar of New Testament Greek, by J.H. Moulton (Edinburgh, Clark 1963) 81-82; K.L. McKay, 'On the Perfect and Other Aspects in the Greek Non-Literary Papyri', Bulletin of the Institute of Classical Studies 27 (1980) 23-49; C.F.D. Moule, An Idiom Book of New Testament Greek (2nd ed.; Cambridge, Cambridge University Press 1959) 18.

118Besides Porter, Verbal Aspect, ch. 5, see J.P. Louw, 'Die Semantiese Waarde van die Perfektum in Hellenistiese Grieks', Acta Classica 10 (1967) 23-32. 
passage by the early church, 119 or of a later translation of some Hebrew or Aramaic word originally used by Jesus. ${ }^{120}$ There are several responses that might be made to these assertions. The first is the recognition that there are several conceptually parallel phrases in the Gospels, indicating that even though the

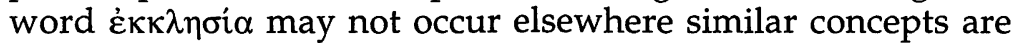
present. 121 The hypothesis of a Semitic Vorlage does not solve the problem, however, since the translational tendency of the redactor cannot be established with any certainty on the basis of such limited evidence. The Semitic words are at best only general conceptual equivalents, and often not even that (in the light of the use of $\dot{\varepsilon} \kappa \lambda \eta \sigma^{\prime} \alpha$ in ancient Greek). The second response is that the objection to Jesus using the word $\dot{\varepsilon} \kappa \kappa \lambda \eta \sigma i \alpha$ seems to neglect several important linguistic factors. The use of

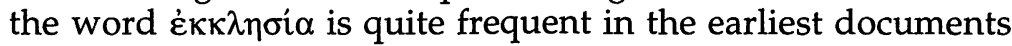
of the New Testament, namely Paul's letters, as well as Acts. It is plausible that use of $\dot{\kappa} \kappa \lambda \eta{ }^{\prime} i \alpha$ was adopted because of the use of this word by Jesus himself here in Matthew 16:18 and $18: 17$, the use of a common Greek word to refer to a group of people gathered for a purpose. In 16:18 the word seems to refer to an idealized assembly or gathering of Jesus' followers (i.e. the universal church), whereas in 18:17 a specific body of followers seems to be referred to, perhaps as an instantiation of the idealized group. Both uses are found in pre-New Testament Greek literature. Whereas in Herodotus $\dot{\varepsilon} \kappa \kappa \lambda \eta \sigma i \alpha$ is used simply of a meeting or gathering of people, during the Attic period it could be used of the authoritative Athenian political body (see Plato, Gorg. 452E, 456B; Thucydides 2.22.1; and numerous inscriptions), or it could refer to other assemblies gathered for various purposes (see Euripides, Rhesus 139; Xenophon, Anab. 1.32). The more general meaning seems to have been constricted through a process of lexical conservatism to refer to early Christian gatherings and then was applied to the whole church, although the general usage also persisted (e.g. Acts 19:39).122 Thus, assuming that Jesus spoke Greek, as it

${ }^{119}$ See Gundry, Matthew, 335; Robinson, 'Peter and his Successors', esp. 9091.

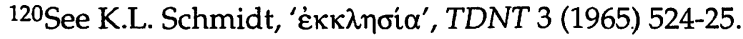

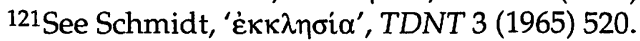

122See A. Hilhorst, 'Termes chrétiens issues du vocabulaire de la démocratie athénienne', Filología Neotestamentaria $1(1 ; 1988) 29$; J.Y. Campbell, 'The Origin and Meaning of the Christian Use of the Word 
has been shown above seems clearly to be the case, there is no linguistic restriction on his using the term $\dot{\varepsilon} \kappa \kappa \lambda \eta \sigma i \alpha$ here to refer to his gathered followers. In fact, since again this vocabulary is not a part of Matthew's redactional tendency, or any of the Gospels' for that matter, it appears possible if not likely that these words go back to Jesus himself.

Other issues could be mentioned in this passage in support of the hypothesis that Jesus delivered these words in Greek. Those who might argue that the use of oujpavó in the plural is a distinctively Semitic phenomenon must take note first that the plural is used in a number of extra-biblical Greek authors, including Aristotle, and secondly that Matthew himself uses both the singular and the plural (Mt. 5:34-35; 6:10; 6:19-20, as well as 18:18, use the singular), making it difficult to establish clear patterns of usage that point to an Aramaic substratum.123 There is also the use of the phrasing regarding Hades. Although there are numerous parallels to this phrasing in Old Testament literature (e.g. Job 17:16; 38:17; Ps. 9:13; 107118; Is. 38:10) and noncanonical literature (Wis. 16:13; 3 Macc. 5:51; Ps. Sol. 16:2), there are also of course numerous parallels in secular Greek literature, since the image of Hades is a traditional classical one (e.g. Homer, Il. 9.312; Od. 11.277; Aeschylus, Ag. 1291; Euripides, Hec. 1).124 And lastly, regarding the concepts of binding and loosing, whereas there are several proposals that rely on Semitic thought (not necessarily excluded even if Jesus delivered the words in Greek!), the most likely proposal relies upon a literary parallel from Josephus (J.W. 1.111), where he refers to the Pharisees as ingratiating themselves to the empress Alexandra so that they might 'loose

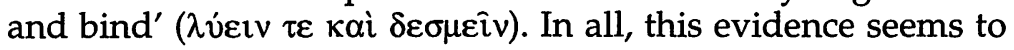
point to Matthew recording a tradition that is related to Mark and Luke but independent of theirs and formulated early in

EKK $\Lambda \mathrm{H} \Sigma \mathrm{IA}^{\prime}$, JTS 49 (1948) 130-42; M. Silva, Biblical Words and their Meaning: An Introduction to Lexical Semantics (Grand Rapids, Zondervan 1983) $26,79$.

123W.G. Thompson (Matthew's Advice to a Divided Community: Matt 17:2218:35 [Rome, Pontifical Biblical Institute 1970] 189) notes that the compound phrase 'heaven and earth' (e.g. Mt. 5:18; 11:25; 24:35; 28:18) signifies a totality. The words are probably used in terms of spheres of existence.

${ }^{124}$ D.A. Carson, 'Matthew', in The Expositor's Bible Commentary (11 vols.; ed. F.E. Gaebelein; Grand Rapids, Zondervan 1984) Vol. 8, 370. 
Greek. The tenor of the discussion in Matthew's Gospel, in which Peter is depicted independently of Mark's account as the representative disciple, 125 and in which Peter's confession is followed by Peter's rebuke, points toward Jesus having delivered these words in Greek very similar to that found here in the canonical text.

\section{Conclusion}

In conclusion, it seems to me that the evidence regarding what is known about the use of Greek in ancient Palestine, including the cosmopolitan hellenistic character of lower Galilee, the epigraphic and literary evidence, including coins, papyri, literary writers, inscriptions and funerary texts, but most of all several significant contexts in the Gospels, all points in one direction: whereas it is not always known how much and on which occasions Jesus spoke Greek, it is virtually certain that he used Greek at various times in his itinerant ministry. It is probable that we have his actual words in Mark 15:2 and parallels, and may well have a passage of his teaching originally delivered in Greek recorded in Matthew 16:17-19. This says nothing about the overall linguistic competence of Jesus, nor do we know the frequency with which he used the languages at his disposal. But this conclusion at least opens up the possibility of further exploration of this topic, since it must be recognized that this conclusion has a solid foundation and cannot be ruled out on the basis of presupposition alone. ${ }^{126}$

125J.D. Kingsbury, 'The Figure of Peter in Matthew's Gospel as a Theological Problem', JBL 98 (1979) esp. 72-73.

${ }^{126}$ In a sequel to this article I hope to deal with further NT texts which support the approach developed here. 